\title{
UPAYA MENINGKATKAN KOMPETENSI GURU DALAM PENGUASAAN KURIKULUM 2013 MELALUI IN SERVICE TRAINING
}

\author{
Martinus Widodo \\ SD Negeri 2 Sendangrejo \\ martindo6411@gmail.com
}

\begin{abstract}
Abstrak
Tujuan penelitian ini adalah untuk meningkatkan kompetensi guru dalam penguasaan Kurikulum 2013 melalui in-service training. Penelitian ini merupakan Penelitian Tindakan Sekolah yang dilaksanakan dalam 2 (dua) siklus. Tempat penelitian yaitu SD Negeri 2 Sendangrejo dengan subjek penelitian berjumlah 8 orang guru. Penilaian kemampuan guru dilakukan dengan teknik observasi dengan lembar observasi. Validasi data dilakukan dengan teknik triangulasi. Analisis data dilakukan dengan teknik analisis deskriptip komparatif. Setelah diberikan tindakan pada siklus I dan siklus II diketahui bahwa kompetensi guru dalam menguasai kurikulum 2013 mengalami peningkatan. Hasil tersebut menunjukkan bahwa In Service Training terbukti dapat meningkatkan kompetensi guru dalam menguasai kurikulum 2013 di SD negeri 2 Sendangrejo.
\end{abstract}

Kata kunci: kompetensi guru, Kurikulum 2013, in-service training

\begin{abstract}
The purpose of this study is to improve teacher competence in mastering the 2013 Curriculum through inservice training. This research is a school action research conducted in 2 (two) cycles. The place of research is SD Negeri 2 Sendangrejo with 8 teachers as research subjects. Assessment of teacher abilities is carried out by observation techniques with observation sheets. The data validation was done by using triangulation technique. Data analysis was performed using comparative descriptive analysis techniques. After taking action in cycle I and cycle II, it is known that the competence of teachers in mastering the 2013 curriculum has increased. These results indicate that In Service Training has been proven to improve teacher competence in mastering the 2013 curriculum at SD Negeri 2 Sendangrejo.
\end{abstract}

Keywords: teacher competence, 2013 curriculum, in-service training

\section{PENDAHULUAN}

Menciptakan seorang guru yang profesional merupakan sebuah peran penting yang berarti untuk terbentuknya sekolah yang unggul. Guru merupakan profesi mulia yang tidak semua orang bisa menjalaninya dengan baik (Nurgiansah \& Sukmawati, 2020). Ketika guru profesional sudah memiliki banyak pengalaman mengajar, maka intelektual, moral, keimanan, dan juga sikap disiplin serta tanggungjawab nantinya akan meningkat. Wawasan kependidikan seorang guru yang luas sangat di butuhkan. Selain dari pada itu kemampuan manajerial, trampil, kreatif, memiliki keterbukaan yang profesional untuk memahami beberapa potensi dari anak didik, karakteristik dan masalah perkembangan peserta didik, mampu mengembangkan progres dari rencana studi dan karir dari seorang peserta didik dalam mengembangkan kurikulum yang diajarkanya (Asmini, 2018).

Kurikulum merupakan salah satu unsur sumberdaya pendidikan yang memberikan kontribusi signifikan untuk mewujudkan proses berkembangnya kualitas potensi peserta didik. Kurikulum 2013 didesain berdasarkan pada budaya dan karakter bangsa, berbasis peradaban, dan berbasis pada kompetensi (Ikhsan \& Hadi, 2018). Dengan demikian, Kurikulum 2013 diyakini mampu mendorong terwujudnya manusia Indonesia yang bermartabat, beradab, berbudaya, berkarakter, beriman dan bertakwa kepada Tuhan Yang Maha Esa, berakhlak mulia, sehat, berilmu, cakap, kreatif, 
mandiri, dan menjadi warga negara yang demokratis, bertanggung jawab, serta mampu menghadapi berbagai tantangan yang muncul di masa depan (Muzamiroh, 2013). Pemahaman guru tentang kurikum akan menentukan rancangan guru (Rencana Program Pembelajaran/RPP) dan diterjemahkan dalam bentuk kegiatan pembelajaran. Pembelajaran harus memberikan kesempatan yang luas kepada peserta didik untuk mengembangkan dirinya menjadi hasil belajar yang sama atau lebih tinggi dari yang dinyatakan dalam Standar Kompetensi Lulusan (Rahayu, 2016).

Fenomena di lapangan yang diketahui dari hasil observasi pada tanggal 16 September 2019, yang dilakukan peneliti selaku Kepala SD Negeri 2 Sendangrejo pada saat Kegiatan Belajar Mengajar (KBM) berlangsung, terlihat beberapa atau sebagian besar siswa belum mampu mengikuti proses pembelajaran secara optimal. Selama proses pembelajaran, potensi para siswa kurang diberdayakan sehingga sebagian besar siswa belum mampu mencapai kompetensi individual yang diperlukan untuk mengikuti pelajaran lanjutan. Beberapa siswa belum belajar sampai pada tingkat pemahaman. Siswa belum mampu mempelajari fakta, konsep, prinsip, hukum, teori, dan gagasan inovatif lainnya pada tingkat ingatan, peserta didik belum dapat menggunakan dan menerapkannya secara efektif dalam pemecahan masalah sehari-hari yang kontekstual.

Pembelajaran adalah proses interaksi antara peserta didik (Nurgiansah et al., 2021). Hal ini menunjukkan bahwa proses pembelajaran yang terjadi di dalam kelas selama ini masih menggunakan proses pembelajaran konvensional, belum mengarah kepada Penilaian HOTS Kurikulum 2013 (Dinni, 2018). Inti dari Kurikulum 2013, adalah ada pada upaya penyederhanaan, dan tematik-integratif.
Kurikulum 2013 disiapkan untuk mencetak generasi yang siap di dalam menghadapi masa depan. Karena itu kurikulum disusun untuk mengantisipasi perkembangan masa depan (Lestari, 2018). Titik beratnya, bertujuan untuk mendorong siswa, mampu lebih baik dalam melakukan observasi, bertanya, bernalar, dan mengkomunikasikan (mempresentasikan), apa yang mereka peroleh atau mereka ketahui setelah menerima materi pembelajaran.

Hasil penilaian terhadap guru-guru SD Negeri 2 Sendangrejo Tahun Pelajaran 2019/2020 menunjukkan bahwa nilai ratarata kompetensi guru dalam penguasaan Penilaian HOTS Kurikulum 2013 adalah 59,7 dengan kualifikasi C (Cukup). Artinya sebagian besar guru belum memahami Penilaian HOTS Kurikulum 2013 dan belum menerapkan Penilaian HOTS Kurikulum 2013 dalam kegiatan pembelajaran di kelas.

Menurut Newman dan Wehlage (Widodo, 2013:162) dengan higher order thinking peserta didik akan dapat membedakan ide atau gagasan secara jelas, berargumen dengan baik, mampu memecahkan masalah, mampu mengkonstruksi penjelasan, mampu berhipotesis dan memahami hal-hal kompleks menjadi lebih jelas. Menurut Vui (Kurniati, 2014:62) higher order thinking skills akan terjadi ketika seseorang mengaitkan informasi baru dengan infromasi yang sudah tersimpan di dalam ingatannya dan mengaitkannya dan/atau menata ulang serta mengembangkan informasi tersebut untuk mencapai suatu tujuan atau menemukan suatu penyelesaian dari suatu keadaan yang sulit dipecahkan.

Tujuan utama dari higher order thinking skills adalah bagaimana meningkatkan kemampuan berpikir peserta didik pada level yang lebih tinggi, terutama yang berkaitan dengan 
kemampuan untuk berpikir secara kritis dalam menerima berbagai jenis informasi, berpikir kreatif dalam memecahkan suatu masalah menggunakan pengetahuan yang dimiliki serta membuat keputusan dalam situasi-situasi yang kompleks (Saputra, 2016:91-92).

Untuk mengatasi masalah yang dialami guru-guru tersebut, peneliti selaku kepala SD Negeri 2 Sendangrejo melaksanakan Penelitian Tindakan Sekolah dengan menggunakan In service Training secara intensif dan optimal untuk meningkatkan kompetensi guru dalam penguasaan Penilaian HOTS Kurikulum 2013 di SD Negeri 2 Sendangrejo pada semester 1 Tahun Pelajaran 2019/2020 . Program in service training adalah suatu usaha pelatihan atau pembinaan yang memberi kesempatan kepada seseorang yang mendapat tugas jabatan tertentu dalam hal tersebut adalah guru, untuk mendapat pengembangan kinerja (Afrilian et al., 2017). In service training juga bisa dikatakan sebagai suatu program sekaligus metode pelatihan dan pendidikan dalam jabatan yang dilaksanakan dengan cara langsung bekerja di tempat untuk belajar dan meniru suatu pekerjaan dibawah bimbingan seorang pengawas (Purwanto, 2012:96). Dalam kegiatan in-service training, guru dibimbing secara langsung dan intens untuk membantu belajar lebih efektif, sehingga diharapkan kompetensi guru dalam penguasaan Penilaian HOTS Kurikulum 2013 akan meningkat.

Dengan penerapan in-service training diharapkan; (1) guru memahami Penilaian HOTS Kurikulum 2013 secara keseluruhan, (2) guru mengaplikasikan Penilaian HOTS Kurikulum 2013 dalam proses pembelajaran, dan (3) guru dapat meningkat kualitas kinerjanya.

\section{METODE PENELITIAN}

Lokasi penelitian ini adalah SD Negeri 2 Sendangrejo yang beralamat di Desa
Sendangrejo, Kecamatan Baturetno, Kabupaten Wonogiri. Alasan pemilihan tempat penelitian ini adalah karena peneliti sebagai kepala SD Negeri 2 Sendangrejo sehingga mengetahui adanya indikasi rendahnya kompetensi guru dalam penguasaan Penilaian HOTS pada Kurikulum 2013. Subjek penelitian ini yaitu guru SD Negeri 2 Sendangrejo semester 1 Tahun Pelajaran 2019/2020 yang berjumlah 8 orang. Objek penelitian ini adalah kompetensi guru SD Negeri 2 Sendangrejo dalam penguasaan Penilaian HOTS Kurikulum 2013 dan penerapan InService Training.

Instrumen penelitian ini yaitu lembar observasi mengenai kemampuan guru dalam menguasai kurikulum 2013. Validasi data pada penelitian ini menggunakan teknik triangulasi yaitu untuk penilaian hasil pengamatan kompetensi guru dalam penguasaan Penilaian HOTS Kurikulum 2013 dengan membandingkan hasil penilaian kondisi awal, siklus I dan siklus II. Teknik analisis data kompetensi guru dalam penguasaan Penilaian HOTS Kurikulum 2013 menggunakan analisis deskriptif komparatif yaitu membandingkan hasil penilaian kompetensi guru dalam penguasaan Penilaian HOTS Kurikulum 2013 kondisi awal dengan hasil penilaian kompetensi guru dalam penguasaan Penilaian HOTS Kurikulum 2013 pada siklus I dan terakhir dengan penilaian kompetensi guru dalam penguasaan Penilaian HOTS Kurikulum 2013 pada siklus II.

Selanjutnya, indikator keberhasilan penelitian tindakan ini yaitu: 1) adanya peningkatan kompetensi guru dalam penguasaan Penilaian HOTS Kurikulum 2013 dari kondisi awal ke siklus I dan dari siklus I ke siklus II, 2) adanya peningkatan kualitas kompetensi guru pada proses pembelajaran dengan indikasi guru memahami dan menguasai Penilaian HOTS Kurikulum 2013 dan mampu mengaplika- 
sikannya dalam kegiatan pembelajaran di kelas dari kondisi awal ke siklus I dan dari siklus I ke siklus II.Tahap-tahap yang dilakukan dalam penelitian ini adalah: (1) tahap refleksi awal, (2) tahap perencanaan, (3) tahap pelaksanaan tindakan, (4) tahap observasi dan (5) Tahap refleksi. Jika digambarkan, siklus kerja PTS adalah sebagai berikut.

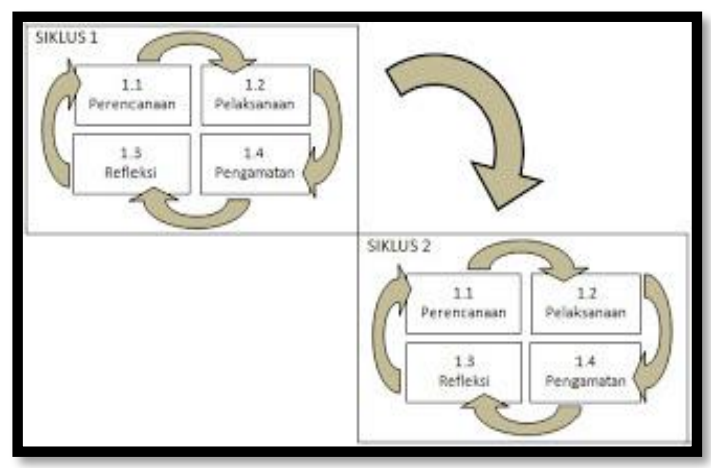

Gambar 1. Prosedur Penelitian Tindakan Sekolah

\section{HASIL PENELITIAN DAN PEMBAHASAN Hasil Penelitian \\ Deskripsi Pratindakan}

Selama proses pembelajaran, potensi para siswa kurang diberdayakan sehingga sebagian besar siswa belum mampu mencapai kompetensi individual yang diperlukan untuk mengikuti pelajaran lanjutan. Beberapa siswa belum belajar sampai pada tingkat pemahaman. Siswa belum mampu mempelajari atau menghafal fakta, konsep, prinsip, hukum, teori, dan gagasan inovatif lainnya pada tingkat ingatan, peserta didik belum dapat menggunakan dan menerapkannya secara efektif dalam pemecahan masalah seharihari yang kontekstual. Hal ini menunjukkan bahwa proses pembelajaran yang terjadi di dalam kelas selama ini masih menggunakan proses pembelajaran konvensional, belum mengarah kepada Penilaian HOTS Kurikulum 2013. Adapun tabel hasil penilaian kompetensi guru dalam penguasaan Penilaian HOTS
Kurikulum 2013 pada kondisi awal dapat dilihat pada tabel berikut.

Tabel 1. Hasil Penilaian Kompetensi Guru Pada Kondisi Awal

\begin{tabular}{|c|c|c|}
\hline No & Kualifikasi & Jumlah \\
\hline 1 & Amat Baik & - \\
2 & Baik & 2 orang $(25,0 \%)$ \\
3 & Cukup & 3 orang $(37,5 \%)$ \\
4 & Kurang & 3 orang $(37,5 \%)$ \\
\hline & Rata-rata & $\mathbf{5 9 , 7}$ \\
\hline & Predikat & Cukup \\
\hline
\end{tabular}

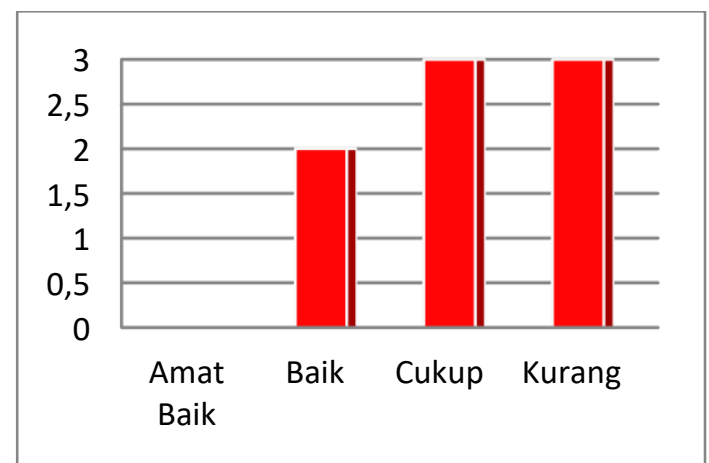

Gambar 2. Grafik Hasil Penilaian Kompetensi Guru pada Kondisi Awal

Pada kondisi awal, sebelum diterapkan In-service training, tidak ada guru yang kompetensi penguasaan Penilaian HOTS Kurikulum 2013 masuk kualifikasi Amat Baik, hanya 2 orang guru $(25,0 \%)$ yang kompetensinya masuk kualifikasi Baik, 3 orang guru $(37,5 \%)$ yang kompetensinya masuk kualifikasi Cukup dan masih ada 3 orang guru $(37,5 \%)$ yang kompetensinya masuk kualifikasi Kurang. Nilai rata-rata kompetensi guru adalah 59,7 dengan kualifikasi Cukup. Artinya sebagian besar guru belum memahami Penilaian HOTS Kurikulum 2013 dan belum menerapkan Penilaian HOTS Kurikulum 2013 dalam kegiatan pembelajaran di kelas. Untuk mengatasi permasalahan rendahnya kompetensi guru SD Negeri 2 Sendangrejo Tahun Pelajaran 2019/2020 dalam penguasaan Penilaian HOTS Kurikulum 2013 , maka peneliti akan melaksanakan suatu Penelitian Tindakan Sekolah melalui in-service training. 


\section{Siklus I}

Siklus I dilaksanakan dalam tiga kali pertemuan. Pertemuan pertama dan kedua untuk pelaksanaan In-service training dengan bimbingan kelompok dan individu, pertemuan ketiga untuk evaluasi penilaian kompetensi guru. Pengamatan terhadap pelaksanaan tindakan, yaitu menitikberatkan pada kompetensi guru dalam penguasaan Penilaian HOTS Kurikulum 2013 setelah diterapkan Inservice training dengan bimbingan kelompok dan individu. Kegiatan guru peserta diobservasi, baik menyangkut kesiapan mental dan fisik guru, kehadiran guru, kualitas pembelajaran setelah Inservice training. Dari hasil pengamatan terhadap aktivitas guru peserta dengan menggunakan lembar observasi yang telah disiapkan, diperoleh data sebagai berikut.

Tabel 2. Hasil Penilaian Kompetensi Guru Pada Siklus I

\begin{tabular}{|c|c|c|}
\hline No & Kualifikasi & Jumlah \\
\hline 1 & Amat Baik & 2 orang $(25,0 \%)$ \\
2 & Baik & 3 orang $(37,5 \%)$ \\
3 & Cukup & 3 orang $(37,5 \%)$ \\
4 & Kurang & - \\
\hline \multicolumn{2}{|c|}{ Rata-rata } & $\mathbf{7 3 , 9}$ \\
\hline \multicolumn{2}{|c|}{ Predikat } & Baik \\
\hline
\end{tabular}

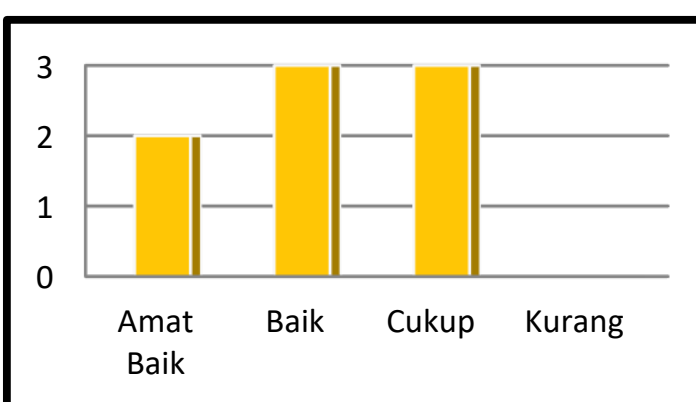

Gambar 3. Grafik Hasil Penilaian Kompetensi Guru pada Siklus I

Pada siklus I, kepala sekolah sudah melaksanakan In-service training dengan bimbingan kelompok dan individu. Ada 2 orang guru $(25,0 \%)$ yang kompetensi penguasaan Penilaian HOTS Kurikulum 2013 masuk kualifikasi Amat Baik, 3 orang guru $(37,5 \%)$ yang kompetensinya masuk kualifikasi Baik, 3 orang guru $(37,5 \%)$ yang kompetensinya masuk kualifikasi Cukup dan tidak ada guru yang kompetensinya masuk kualifikasi Kurang. Nilai rata-rata kompetensi guru adalah 73,9 dengan kualifikasi Baik. Artinya sebagian guru sudah memahami dan menerapkan Penilaian HOTS Kurikulum 2013 tetapi sebagian belum memahami dan menerapkan Penilaian HOTS Kurikulum 2013 dalam kegiatan pembelajaran di kelas. Kompetensi guru SD Negeri 2 Sendangrejo dalam penguasaan Penilaian HOTS Kurikulum 2013 pada siklus I sudah menunjukkan peningkatan, namun peningkatannya masih belum memenuhi kriteria indikator kinerja penelitian sehingga perlu diberikan tindakan pada siklus II

\section{Siklus II}

Pada siklus II, kepala sekolah menerapkan In-service training dengan diskusi dan micro teaching. Sesuai dengan refleksi hasil siklus I, langkah-langkah yang diambil pada dasarnya memiliki prosedur yang sama dengan siklus I, hanya saja diadakan perbaikan pada hal-hal yang dilihat ada kelemahan serta mempertahankan hal-hal yang sudah berjalan dengan baik. dengan memfokuskan pada penjelasan aspekaspek yang belum dipahami guru lebih menitikberatkan pada aspek pembimbingan secara kelompok. Hasil penilaian kompetensi guru SD Negeri 2 Sendangrejo dalam penguasaan Penilaian HOTS Kurikulum 2013 dapat dilihat pada tabel berikut.

Tabel 3. Hasil Penilaian Kompetensi Guru Pada Siklus II

\begin{tabular}{|c|c|c|}
\hline No & Kualifikasi & Jumlah \\
\hline 1 & Amat Baik & 3 orang $(37,5 \%)$ \\
2 & Baik & 5 orang $(62,5 \%)$ \\
3 & Cukup & - \\
4 & Kurang & - \\
\hline
\end{tabular}




\begin{tabular}{|c|c|}
\hline Rata-rata & $\mathbf{8 3 , 8}$ \\
\hline Predikat & Baik \\
\hline
\end{tabular}

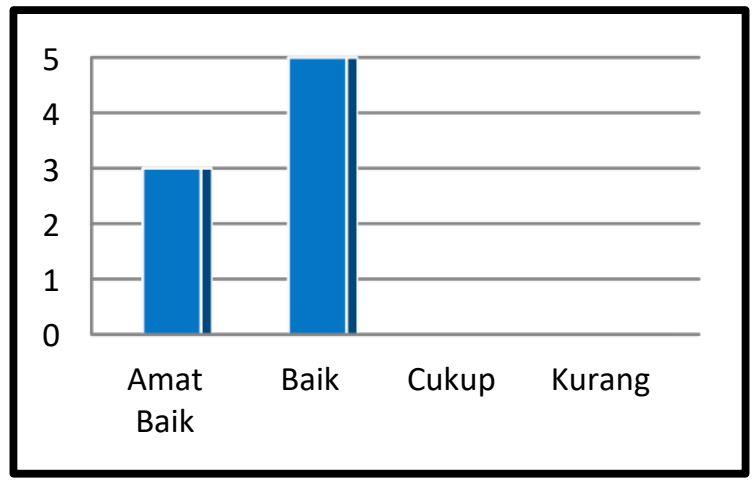

Gambar 4. Grafik Hasil Penilaian Kompetensi Guru pada Siklus II

Pada siklus II, kepala sekolah menerapkan In-service training dengan diskusi dan micro teaching. Ada 3 orang guru $(37,5 \%)$ yang kompetensinya masuk kualifkasi Amat Baik, sebanyak 5 orang guru $(62,5 \%)$ yang kompetensinya masuk kualifikasi Baik dan tidak ada guru yang kualifikasi Cukup maupun Kurang. Nilai rata-rata kompetensi guru adalah 83,8 masuk kualifikasi Baik. Artinya semua guru sudah memahami dan sudah menerapkan Penilaian HOTS Kurikulum 2013 dalam kegiatan pembelajaran di kelas. Oleh karena, peneliti tidak perlu melaksanakan tindakan pada siklus berikutnya.

\section{Pembahasan}

Kurikulum merupakan perangkat penting dalam dunia pendidikan. Melalui kurikulum, guru memiliki pedoman mengenai arah pembelajaran yang akan diberikan kepada peserta didik. Perkembangan zaman mengharuskan guru untuk terus berkembang dan meningkatkan kompetensinya (Nurgiansah \& Pringgowijoyo, 2020). Salah satu kurikulum pendidikan yang diterapkan di Indonesia yaitu kurikulum 2013. Dinamakan kurikulum 2013 karena kurikulum ini diresmikan oleh menteri pendidikan pada tahun 2013. Di dalam kurikulum 2013 terdapat penilaian HOTS.
HOTS merupakan kepanjangan dari Higher Older Thinking Skills . Higher Older Thinking Skills merupakan suatu proses berpikir peserta didik dalam level kognitif yang lebih tinggi yang dikembangkan dari berbagai konsep dan metode kognitif dan taksonomi pembelajaran seperti metode problem solving, taksonomi bloom, dan taksonomi pembelajaran, pengajaran, dan penilaian (Saputra, 2016:91). HOTS (High Order Thinking Skill) yaitu kemampuan berfikir tinggi yang mulai diterapkan di berbagai jenjang dan jenis pendidikan (Nurgiansah, 2019). Higher order thinking skills ini meliputi di dalamnya kemampuan pemecahan masalah, kemampuan berpikir kreatif, berpikir kritis, kemampuan berargumen, dan kemampuan mengambil keputusan. Menurut King, higher order thinking skills termasuk di dalamnya berpikir kritis, logis, reflektif, metakognitif, dan kreatif.

Guru harus mengembangkan profesionalnya melalui berbagai kegiatan profesi (Nurgiansah, 2021). Rendahnya kemampuan guru dalam menguasai penilaian HOTS pada kurikulum 2013 dapat dientaskan melalui penerapan Inservice Training. Permasalahan rendahnya kompetensi guru SD Negeri 2 Sendangrejo pada semester 1 Tahun Pelajaran 2019/2020 pada pelaksanaan Penilaian HOTS Kurikulum 2013 disebabkan karena kurangnya program pembinaan kepada guru terkait dengan penerapan Penilaian HOTS Kurikulum 2013 . Untuk mengatasi permasalahan tersebut, maka peneliti selaku kepala SD Negeri 2 Sendangrejo merancang Penelitian Tindakan Sekolah melalui pelaksanaan kegiatan in-service training. Setelah dilaksanakan tindakan dalam pada siklus I dan siklus II, diperoleh data peningkatan kompetensi guru SD Negeri 2 Sendangrejo pada semester 1 Tahun Pelajaran 2019/2020 pada pelaksanaan Penilaian HOTS Kurikulum. Hasil penelitian ini mendukung dari apa 
yang sudah dilakukan oleh (Afrilian et al., 2017) dan (Sakarti, n.d.) dimana In service training dapat digunakajn untuk meningkatkan profesionalisme guru.

\section{KESIMPULAN}

Berdasarkan data dari hasil penelitian ini, maka dapat disimpulkan bahwa in-service training dapat meningkatkan kompetensi guru SD Negeri 2 Sendangrejo semester 1 Tahun Pelajaran 2019/2020 dalam penguasaan Penilaian HOTS Kurikulum 2013 .

\section{DAFTAR PUSTAKA}

Afrilian, D., Fitriana, E., Wijanarko, F., Rianti, L., \& Hidayat, R. (2017). In Service Training Dalam Peningkatan Profesionalisme Guru. 1.

Dinni, H. N. (2018). HOTS ( High Order Thinking Skills ) dan Kaitannya dengan Kemampuan Literasi Matematika. Prisma, 1, 170-176.

Ikhsan, K. N., \& Hadi, S. (2018). Implementasi dan Pengembangan Kurikulum 2013. In Jurnal Edukasi (Ekonomi, Pendidikan dan Akuntansi) (Vol. 6, Issue 1, p. 193). https://doi.org/10.25157/je.v6i1.1682

Lestari, N. D. (2018). Analisis Penerapan Kurikulum 2013 Dalam Meningkatkan Kualitas Pembelajaran Ekonomi Di Sma Negeri Se-Kota Palembang. Jurnal Neraca: Jurnal Pendidikan Dan Ilmu Ekonomi Akuntansi, 2(1), 68-79. https://doi.org/10.31851/neraca.v2i1.2190

Nurgiansah, T. H. (2019). Pemutakhiran Kurikulum Pendidikan Kewarganegaraan di Era Revolusi Industri 4.0. Prosiding Seminar Kewarganegaraan Universitas Negeri Medan, 1(1), 95-102.

Nurgiansah, T. H. (2021). Pelatihan Penelitian Tindakan Kelas Bagi Guru Pendidikan Kewarganegaraan Di Sekolah Menengah Atas Se-Kabupaten Bantul. BERNAS: Jurnal Pengabdian Kepada Masyarakat, 2(1), 28-33. https://doi.org/10.31949/jb.v2i1.566

Nurgiansah, T. H., Hendri, \& Khoerudin, C. M. (2021). Role Playing Dalam Pembelajaran Pendidikan Pancasila dan Kewarganegaraan. Jurnal Kewarganegaraan, 18(1), 56-64. https://doi.org/10.24114/jk.v18i1.22597

Nurgiansah, T. H., \& Pringgowijoyo, Y. (2020). Pelatihan Penggunaan Model Pembelajaran Jurisprudensial Pada Guru Di KB TK Surya Marta Yogyakarta. KUAT: Keuangan Umum Dan Akuntansi Terapan. PKNSTAN, 2(1).

Nurgiansah, T. H., \& Sukmawati. (2020). Tantangan Guru Pendidikan Kewarganegaraan Di Masa Adaptasi Kebiasaan Baru. Jurpis: Jurnal Pendidikan Ilmu Sosial, 17(2), 139-149.

Rahayu, Y. M. (2016). Pengaruh perubahan kurikulum 2013 terhadap perkembangan peserta didik. Jurnal Logika, XVIII(3), 22-42.

Sakarti. (n.d.). Service dan Inservice Training Dalam Peningkatan Guru PAI. 